\title{
Deconstructing Indonesian film for Semarang's city branding as a cinematic city
}

\section{Dekonstruksi film Indonesia untuk city branding Semarang kota film}

\author{
Amida Yusriana, Mutia Rahmi Pratiwi \& Mukaromah \\ Department of Communication Studies, Faculty of Computer Science, Dian Nuswantoro University \\ Jalan Imam Bonjol No.207, Semarang, Central Java 50131 \\ E-mail: amida.yusriana@dsn.dinus.ac.id
}

\begin{abstract}
The Variety of Culture is the current city branding concept for Semarang City. It depicts the various cultures and ethnicities that live together in Semarang. However, this city branding is considered insufficient to meet the tourism target. This research aims to develop a new branding for Semarang as a Cinematic City. This concept is derived from the success of several cities which famous as shooting locations, for example Oxford in England, Seoul in South Korea, and New Zealand as the filming sites of The Lord of the Rings. The main aim of this research is to map out the potential locations for Semarang's new branding as a Cinematic City. This research is conducted for three popular movies: Gie, Ayat-Ayat Cinta and Soekarno which those movies used Semarang City as the major filming sites. The result found there are three separated areas in Semarang that can be built as the main points of the city branding. Specifically located in the Old Town District there are Srigunting Park, State Financial Building, Cockfighting site, Berok Bridge, Blenduk Church, Jakarta Lloyd Building, and Berok River. In total, there are nine locations that can be developed as a tourism hub which served as a brand attributes of the effort to construct a Semarang as a Cinematic City. In conclusion, some areas have the potential to be developed into the object of city branding Semarang those are Kota Lama District, Imam Bardjo Auditorium University of Diponegoro and Lawang Sewu Building.
\end{abstract}

Keywords: city branding; Semarang; cinematic city; tourism; strategic communication

\begin{abstract}
Abstrak
Konsep city branding yang dibangun untuk Semarang adalah Variety of Culture. Variety of Culture mengedepankan perbedaan budaya dan etnis yang hidup berdampingan di Semarang. Namun demikian, city branding tersebut belum cukup dalam memenuhi jumlah wisatawan yang datang ke Semarang. Penelitian ini bertujuan mengangkat wacana potensi Semarang sebagai kota film didasarkan pada kesuksesan banyak kota di negara lain yang menjadi terkenal karena lokasi-lokasi syuting filmnya, seperti kota Oxford di Inggris, Seoul di Korea Selatan, dan tempat syuting film terkenal The Lord of The Rings di Selandia Baru. Tujuan utama dari penelitian ini adalah untuk memetakan lokasi yang potensial di kota Semarang untuk branding menjadi kota film. Penelitian ini dilakukan pada tiga film fenomenal di Indonesia, antara lain Gie, Ayat-Ayat Cinta dan Soekarno yang mana mayoritas lokasi syuting dalam ketiga film tersebut adalah di kota Semarang. Hasil menunjukkan terdapat tiga area yang terpisah di Semarang yang dapat dibangun sebagai poin utama untuk branding kota. Area tersebut adalah Distrik Kota Tua yang terdiri dari Taman Srigunting, Gedung Keuangan Negara, tempat menyabung ayam, Jembatan Berok, Gereja Blenduk, Gedung Lloyd Jakarta, dan Sungai Berok. Total seluruhnya terdapat sembilan wilayah potensial yang dapat dikembangkan sebagai pusat turisme yang bisa berperan sebagai brand atribut untuk menkonstruksi kota Semarang sebagai kota film. Kesimpulan dari penelitian ini adalah terdapat beberapa area yang memiliki potensi untuk dikembangkan sebagai objek branding kota Semarang yaitu Distrik Kota Lma, Auditorium Universitas Diponegoro Imam Bardjo dan Gedung Lawang Sewu.
\end{abstract}

Kata kunci: city branding; Semarang; kota film; pariwisata; komunikasi strategis

\section{Introduction}

Tourism has an important role and has a positive impact on state and local revenue. The various tourism concepts to the area that has the potential of basic tourism, tend to increase the added value of the existing areas.So it is expected to attract tourists in large numbers (Lestari \& Firdausi 2017: 261). 
Semarang is the capital of Central Java Province which is a port city on the north coast of Java Island. It is the largest city in Central Java dwelling approximately 1,800,000 population. Recently, Semarang city has been actively building its tourism. In terms of city branding, Semarang has established itself as a city with cultural diversity. The Tagline of Semarang City itself is Variety of Culture. Semarang is different from other cities in Indonesia.

The Semarang's cultural diversity is the main asset to be highlighted, because it is potentially to become the attractive pull factor of the city tourism of Semarang.. this cultural diversity must catalyze many aspects pertaining to the development of city tourism including art, relics and architecture, religions, culinary and other related events. It also is expected to spark the diverse ethnic exists in the city of Semarang, among other Javanese, Coastal, Arabian, and Chinese (semarangkota.go.id 2015). To support city branding, in 2014, there has held a contest of city branding logo and tagline of Semarang. Of the many contestants, it is finally selected a logo that features Warak Ngendog as an icon of Semarang City (metrosemarang.com 2014).

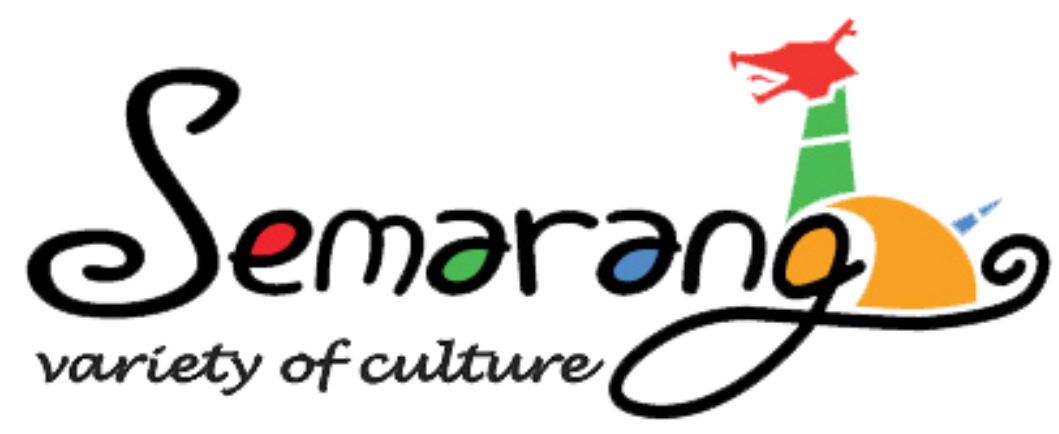

Figure 1.

Semarang City Logo 2014 - Present

Source: http://semarangkota.go.id/berita

Warak Ngendog is a mythological animal describing a unifying symbol of the three major ethnic groups of Semarang. The iconic body consists of the Dragon (China), Buroq (Arabic) and Goat (Java). These animals are usually used as a mascot in dugderan festival which is annually held several days ahead of the Ramadhan fasting month. Regardless of who is the first founder, Warak Ngendog has a philosophical meaning that is always relevant as a guide of human life in any era. The form of custom creatures which is a combination of three ethnic symbols reflects the unity or the acculturation of culture in Semarang. It is said that the characteristic of the straight form of Warak Ngendog illustrates the image of Semarang citizens who are open, straight, and speaking as it is, so there is no difference both in feeling and oral expression.

The concept of city branding used by Semarang is inseparable from the Indonesian government's discourse to realize Indonesia's vision of becoming a tourist destination for 20 million tourists by 2020. Therefore, the Minister of Tourism of Indonesia applies the importance of city branding by utilizing the strength of regional autonomy so as to increase tourism in every region of Indonesia (Antara 2015). Diversity of Culture promotes cultural and ethnic differences that co-exist in Semarang. This includes several aspects of tourism such as crafts, places of worship and culinary. Semarang culinary and places of worship have a uniquely vary including the Grand Mosque of Central Java, Sam Poo Kong Temple, Tay Kak Sie Pagoda, Watugong Buddhagaya Temple, Blendhuk Church, Pura Giri Natha and Avalokitesvara Pagoda. Among the culinary there are various mix of Java, China, and Arabic cuisine.

However, the city branding is considered insufficient to attract the number of tourists expected to coming to Semarang. Even city branding is considered less attractive compared to the likes of Yogyakarta and Bali. The value of the diversity of Culture of the city of Semarang is still likely weak and less socialized. This is similar to a few years ago when Semarang intensively branded itself with a big event called Semarang Pesona Asia in 2007. The event, which many felt as a less prepared one, 
did not succeed in meeting the expected target. Moreover, many officials stumbled on corruption due to the international event (Munif 2014).

In terms of statistics, in May 2015 the number of domestic tourists who visited Central Java reached $30,000,000$. Nevertheless, most of them spent more on the points outside the city of Semarang such as in Borobudur temple. This city has likely had less competitive destinations which is potential to attract local tourist (Huda 2016). This research is expected to create a discourse which is potential for Semarang as a cinematic city following the success of many cities in other countries that became famous for the locations of film shooting. For example, the most world famous is Hollywood. The cinematic city in America which has produced many movie studios built in the middle of the city and specifically developed for film locations. Not only Hollywood city, Hollywood industry has used many locations in America to serve as the background of several famous films. Among many cities in America, one of them is New York which became a tourist destination because of many landmarks that appear in the film.

In addition, New Zealand is also inseparable from the success of the hands of Hollywood directors. Through the trilogy film The Lord of The Rings and The Hobbit, New Zealand became a world tourist destination. Many film backgrounds, such as the most famous Shire built on a small hill in New Zealand and become a tourist rides. Until now, it has become one of the regions producing foreign exchange for the country.

International world scale campus, University of Oxford is also one of the most profits maker since it was the location of filming Harry Potter. The shooting location of the magnificent castle of Hogwarts magic school is widely taken in the halls of the Oxford University campus in England. Therefore, many local businesses are offering a package of daily visits to various sites of the filming the famous movie. One of them is a hall at the Oxford City church that is famous for the location of the Hogwarts dining room shoot.

In Asia, Seoul is the city in South Korea which is also most visited by foreign tourists due to the success of their drama. Nami Island is one of the most well known. Previously, the small island located in Gyeonggi-do province was less famous at all. Yet since the island was bought by the local businessman, it was turned into tourism area and destination. Until then the island became the location of the famous Winter Sonata drama. That drama use the attractiveness and the beauty of the rows of trees, paths and the edge of the lake as ornaments of one scene in the drama. The island only appeared briefly in several episodes, but it turned the Island to become a famous tourist destination not only for local but also foreign tourist. The drama serial was launched in 2002, however Nami Island still continues to be visited until now. Tourism amenities such as Winter Sonata café, bicycle for rent, and photo corner with statues of actors emerge to increase visitors' experience in feeling the sequence of the drama. By knowing the shooting locations on Nami Island, visitors can take pictures and rebuild the movie scenes that are remembered in their memory.

Descendants of The Sun is the latest location of the successful drama of 2016. The film located in a small town called Taebaek. After the dramais finished, the city receives many requests from tourists who want to visit the shooting location of the drama. Therefore, the local government is currently rebuilding the movie set that has actually been dismantled after the drama is over. According to the first plan, the location of the film will be a sustainable destination for fans of the drama. This discourse is supported by the President of Korea and plans to involve the Korea Tourism Organization (Ah-young 2016).

The examples of the city that became a tourist destination due to the location of filming not concentrated in one city, but many cities in one country to attract foreign tourists. In case of Semarang, the city has advantages because many of the spots became the filming location of the famous movie. Semarang as a city can adapt the same concept of tourism by managing several points where it has used to shoot famous films in Indonesia. The management of the shooting site can develop sustainable potential destinations that can encourage tourism activities in the surrounding area. 
Semarang City is not a venue in the Indonesian cinematic business sector due to its famous shoot locations. Many Indonesian films have made Semarang as one of the most appropriate place to photograph the life of the screen in the movie. Lawang Sewu and Kota Lama (Old Town) are two areas that are often used as films shooting location including the entitled Soe Hok Gie, Soekarno, Sang Kiai, Ayat-Ayat Cinta, Zahrana Sacred Love, Tanya Tanya, Soegija and the latest is HOS Tjokroaminoto.

The film production took several locations in Semarang. Hanung Bramantyo is one of the directors who often use Semarang as the background of his films. The reason why he chose Semarang was because of the diverse condition of its society. Reflecting on the recent city branding of Semarang the Variety in Culture, Semarang is often glimpsed as a shooting location as it provides a lot of resources both socially consisted of different ethnics and its architectural buildings implying different taste.

Among the films produced in Semarang, Ayat-Ayat Cinta is the most successful and gains attention from the people. Therefore this film can be one potential source to strengthen the city branding of Semarang as a cinematic city. The number of films which has been produced in Semarang should enable encouraging local business such as a movie tour or relating services. In other case, Oxford offers a tour package of shooting location visits, it can also be re-created a movie set to become a community photo location, movie-themed souvenir shops will also be one of the local businesses that can grow with the success of the city branding. Therefore, it is necessary to reconstruct Semarang in order to recapture the potential of Semarang city branding as a cinematic City. This study aims to reconstruct the potential area of Semarang city branding as a cinematic city for Indonesian film.

Research on city branding becomes one of the topics that seems interesting to be studied by the academic community in Indonesia. There have been many previous studies that discussed about the city branding of Semarang both as Semarang Enchantment Asia (Semarang Pesona Asia) or the latest as Variety in Culture. Here are some previous studies that have been done in assessing city branding Semarang City.

In assessing people's perception on the city branding, Februandari (2002) provides critical review of the former branding. This research tried to find out the perceptions about elements of Semarang Pesona City branding since the lack of clarity and specific points of interests are considered as the reason the brand less competitive.. The research was conducted by distributing questionnaires to 100 respondents and 6 travel agent representatives with qualitative and quantitative mix method. Instead, this study offers few elements required to compose city branding of Semarang City such as the unique, culinary, heritage, cheap, friendly, young and cultural diversity (Februandari 2012:1).

The other study examines the relationship between city branding and brand image of Semarang City. Indeed, Soliha et al. (2014) interrogate how they both influence each other's in affecting the decision to visit Semarang City. The study was conducted by conducting a sample on 104 people by using Multiple Regression Analysis of quantitative method. This means that the better implementation of city branding will increase the brand image of Semarang City in visitor perspectives. The brand image significantly influence on the decision to visit the Semarang. That is, the better the creation of brand image Semarang City in the minds of potential visitors will encourage visitor perspectives to decide whether they will come to Semarang. City branding does not necessarily affects the decision to visit the city of Semarang, but its influence through mediation. Brand image mediates the city branding toward the decision to visit Semarang City. It means that, the better the implementation of city branding with the mediation of high brand image Semarang City into visitor perspectives the bigger the potential of the visitors who decide to come to Semarang City (Soliha 2014:1).

Despite discussing on the important branding image has been discussed the aforementioned studies do not provide how does it is applied in the context of Semarang. Therefore this study offers the map out of the potential city images to support the branding city of Semarang that the previous studies have overlooked. However, the previous studies are to be the milestone for this study since.as a cinematic city. In the first study, it can be obtained that one of the forming elements in making of the appropriate brand to compose city branding of Semarang as cinematic city are its uniqueness and 
the involvement of young generations. The cinematic city discourse will utilize national films which are produced in Semarang. The films have targeted young people. Therefore this element has been in accordance with the results of the research above. In addition, this discourse has not been done in other cities in Indonesia before, so that it fulfils the requirement of unique elements. While in the second study, it stated that the brand image mediates the success of city branding. Semarang as the filming location for several great movies got a good brand image because the films have a big impact and considered as a successful films in the market. Therefore Semarang might also gain a good brand image due to the film.

\section{Research Method}

This research employs qualitative research methods. According to Moleong (2010:5-6), qualitative research is a study using a scientific background to interpret the phenomenon that occurs and it can be done by involving various existing methods. This research uses the descriptive approach in reconstruction process. Research with descriptive approach has a tendency to provide a particular description and explanation of a particular event or condition. The purpose of the study with this method is to describe what is happening or happened. There are several activities and attempts which focus to describe, record, analyze and interpret the conditions that currently occur (Kriyantono 2002:24).

The method chosen in this research is the deconstruction method by Jacques Derrida. The purpose of this method is to describe and change the way the reader or the audience thinks. This method tries to read and describe 'text' (writing, speech, thought, reality, film, etc.) that already exists. It analyzes the 'text' to understand the explicit, implicit and hidden meanings (revealing internal inconsistencies or contradictions in 'text'), transforming 'text' and / or 'text meaning' to bring new thinking and understanding (Turner 2016). The characteristic of the deconstruction method is not to undermine the existing understanding, but to elevate or admit the 'others' as a new understanding. The undermined aspect is the claim that only a certain understanding is assumed to be true, whereas another understanding is considered wrong (Turiman 2015:311-312).

The reason why the researcher choose this method is because this research has a tendency in data needing. The expected result obtained from this research is a data location of film making in Semarang that appears in Indonesian national film. The location must be located in Semarang and is expected to have the potential of tourism access, so it can be developed in subsequent research to produce a strategic communication planning city branding of Semarang City. Deconstruction method is appropriate because it accommodates the requirement to build a new meaning of place.

The research is conducted at Dian Nuswantoro University of Semarang and field research conducted in potential areas arising from the national film review. The object of this research are Indonesian national films which has been produced in Semarang. Data are collected during documentation and observation. The documentation is a way of collecting data by putting a meaning on the source of data that being studied. Sutopo (2002:64) states that the method of observation is used to dig the data in the form of events, places or locations and objects, and image recording. Observations were performed on the data source under study. In this case, the data source is divided into two, primary data and secondary data.

Primary data were obtained from national films located in Semarang including as the entitled Gie, Soekarno, and Ayat-Ayat Cinta. Supporting data obtained from additional sources derived from written sources, such as books, articles, or reading material from the internet. The data analysis process in this research is carried out in several stages, as followed: 1) Data collection of national films produced and located in Semarang and determine the potential of further studies through the impact of film in the community, public interest, after effects and film success seen from quantitative data of Indonesian cinema network, 2) Determination of potential national films and deconstruction of the shooting territory in Indonesia, 3) Region mapping by classifying it through the criteria of similarity and proximity of the region, and 4) Potential excavation mapping of pre-determined areas in the third stage. All of the data result of the analysis that have been obtained will be interpreted using the categories of analysis (filling system) that has been predetermined so that the conclusion can be made. 


\section{Result and Discussion}

City branding is an important topic that appeals to academics and policy makers. The competition between cities to attract certain numbers of tourists, investments and talents, as well as to achieve many other objectives, the concept of this brand strategy was adopted from the commercial and practical world in the pursuit of urban scale development, regeneration and quality in life (Dinnie 2011: 30).

City branding developed and became a part of communication science. City branding is simply a self-image owned by a city to define itself in the eyes of the general public. The image is usually a special feature and uniqueness that distinguishes the city with others which potentially is to become an economic appeal.

Simon Anholt in Moilanen \& Rainisto (2009:7) defines city branding as the image management of a destination through the strategic innovation and economic, commercial, social, cultural, and governmental coordination. According to Kavaratzis (2008:8) city branding generally focus on the image management (image) relating to what and how the image will be formed as well as the communication aspects that has been done in the process of image management.

Having understood on what the city branding means by, the next step is to reveal that city branding is one form of brand images. The Brand image is the current view of consumers about a brand (Petrauskaite 2014: 27). The brand image is general abstract, while the city branding is more specific of the consumers' view about a city. Moreover, building the brand image necessarily requires a brand identity. The Brand identity is a distinct and unique character of the product (Petrauskaite 2014: 34). The Brand identity is determined by the appearance of the brand attributes. The Brand attributes are the description of the brand's natural characteristics (Petrauskaite 2014: 36). Object attributes are characteristics or features that may or may not be possessed by objects (Mowen \& Michael 2002: 316). A strong brand must have the following attributes.

\section{Relevance, consistency, and position relevance}

A brand must be relevant. The brand must meet people's expectations and should demonstrate how to fulfill them. Since then, it should imply an attractive performance in order to persuade consumers. A consistent brand signifies what the brand is showing of, and builds consumer confidence in that brand. A brand must be positioned so as to have a place in consumer's mind and make itself desirable than the others.

\section{Credibility, inspiring, and unique}

A strong brand have to conceal what is promised. It drives the working environment to increase the innovation to reach the target. A brand must inspire not only for the customer but also for brands. A strong brand must be different and unique. It must be indistinguishable from other competitors in the market.

\section{Attractiveness}

They must be interesting. Consumers should be able to be attracted to the promises and its realization (http://www.managementstudyguide.com/brand-attributes.html). This research will deconstruct the national film located in Semarang, so that it can bring up brand attributes from the new city branding of Semarang.

Several movies has been produced in Semarang such as the entitled Gie the movie, Ayat-Ayat Cinta and Soekarno. The majority of the location backgrounds are set in the old district area of Semarang. The location setting is not told as Semarang but is arranged in such a way as to be another area in the movie. In the Gie the Movie, Semarang is set to have been seen as Jakarta in the year 1960, while Ayat-Ayat Cinta it is designed as the Cairo of Egypt and Soekarno set the city as Jakarta looks like.

In the Derrida deconstruction method, the original territories will be dissected until a new meaning 
comes from the film. Not all shooting locations will be discussed as potential territories, only certain regions are eligible as iconic. The steps taken are to describe and then construct.

\section{Gie the movie}

The film is based on the life story of Soe Hok Gie, a young Chinese descendant, also known as a critical activist and writer in the 1960s. Since the childhood, Gie-his nickname, has shown different perspective and attitude in seeing the life compared to his counterparts. Not only that he is honest, straight, but also courageous and brave. His attitude was not unlikely and common in that period, so it is hard for other people to understand him. During the adulthood, Gie's struggle is more complicated. Campus which should be sterile from the impact of the state political affairs turned out to be the political tricks arena and political intrigue of the party. When the state facing a critical crisis post-G30S, he was active in the movement to overthrow the Old Order regime, but later the new regime emerged. Time passed by. When the people around him begin to adjust to the new regime, he remains an independent human being. His writing at the newspapers attacked everything he thought as improper. As a result, people leave him, including his friends as well as the women he loves. Only nature that can accept and love it for what it is (Milesfilms 2010).

Gie the movie was filming in several places around Semarang City. The actual background of this movie was in Jakarta around 1960s, but Kota Lama (the old Town) of Semarang was considered as a perfect place to describe Gie's living milieu in that era. Some of the most widely used areas in Semarang are Srigunting Park, Gajah Mada Street Intersection, Imam Barjo Auditorium of Universitas Diponegoro and the State Financial Building Old Town, Berok Bridge Old Town, Menara Layur Mosque, etc. Among many of the areas, there are several places that considered iconic, such as Imam Barjo Auditorium Diponegoro University, Srigunting Park and State Finance Building Old Town. The selection of the three areas is because they appear in more than one scene and have meaning in the film.

\section{Srigunting Park}

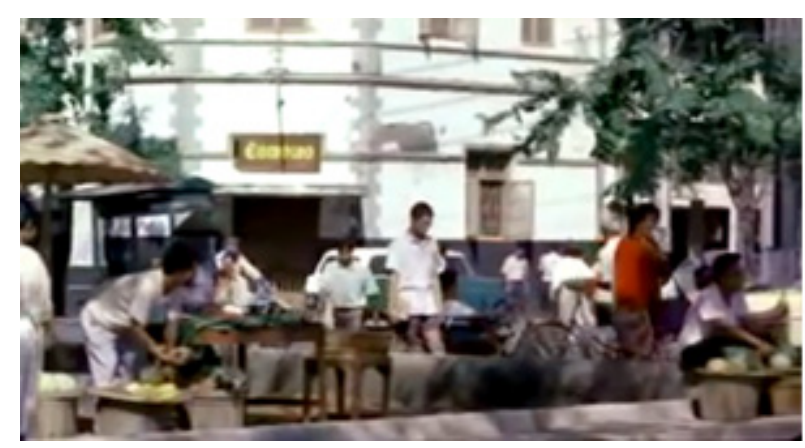

Figure 2.

Srigunting Park changed into public town square in the Gie the movie

This park was chosen to be deconstructed meaning because it appears several time in the movie (Fig.2). This park is considered iconic because it shows a pretty important activities of Gie in the movie. Some of Gie's life experiences which affect the story content occur in this setting. Srigunting park is a public park located in old town district area. In the colonial era this park was a stage parade (Parade de Plein). However, this park has become a public space which can be used for the society around Semarang to gather or doing some community activities.

Srigunting Park has been restored for several times in 2001, the park was restored its function as an open space for recreation that was initially passive. Then it was re-renovated on 2004 by constructing several entrances on various sides. In total, there are four driveways. Srigunting Park is located at Letjen Suprapto Street No. 32 Old Town area district. 


\section{Srigunting Park construction}

Srigunting Park in the film is not described as the original state but as a market or town square. There is no specific street names or identities specified from this park. The park is transformed into a public area and there are many traders sell things. The important scenes which were taken in this area are as followed: a) the time when Gie's Mother took his report and he was declared that he can't upgrade to the next class due to his critical thought. The disappointed Gie was following behind his mother, b) When Gie was about to take revenge on his teacher who gave him a bad grade. He and his friends followed that teacher and passed through this area, and c) When Gie just finishes his demonstration and bought him a drink under the shade of trees in that area. Then came Gie's mother who expelled him from the house because of Gie's actions that were considered to endanger the family.

All of the three scenes are quite iconic and can produce a new image of the park as the Gie milieu facing the crossroads of his life. It is considered as a crossroads of life because of every scene that appears will change Gie's life. When he has to stay in the same class and gets angry at his teacher but does not take revenge for seeing the teacher's life difficulties and when he has to leave home for being thrown out by his mother. This park can have a new meaning as 'the crossroad of Gie's life' in accordance with the meanings raised in the film.

\section{Imam Barjo Auditorium}

Imam Barjo Auditorium is one of the buildings of Diponegoro University smelting site. This Auditorium is used as a communal activity daily. Nevertheless this auditorium is not opened on regular day. This place is open on a certain activities or occasions. The characteristic of this auditorium is the amount of Loster ventilation and glass doors to anticipate the hot air of Semarang city. Currently, the auditorium is mostly used for activities such as job fair and seminars (Fig.3).

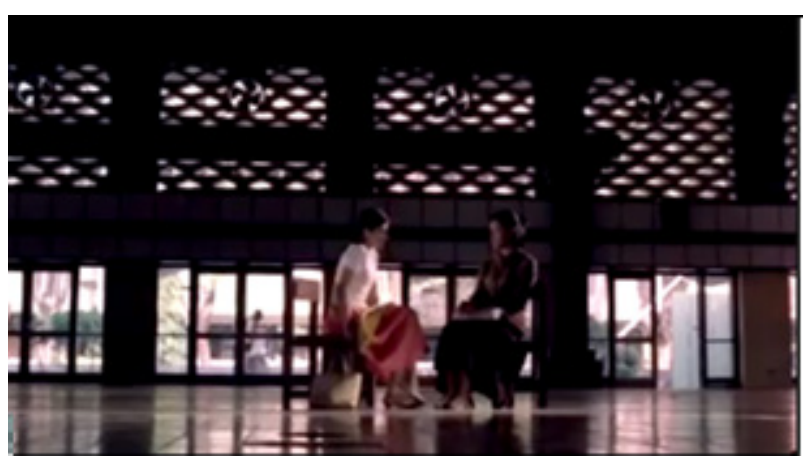

Figure 3.

University of Indonesia Building in the Gie the movie

\section{The reconstruction of Imam Barjo Auditorium}

In the movie, the auditorium is transformed into a hall where students perform film screening and discussion activities. This hall is part of Gie's campus called University of Indonesia. Gie became a very active student voicing his ideas and critical thinking in this area. In some scenes it showed a scene when Gie expressed his opinion, the other scene showed Gie quarrel with one of his friends who became a members of GNI and there were fighting. The last is when Gie's girlfriend, Sinta and Gie's secret crush, Ira spoke to each other. In the scene, Sinta tries to get rid of her anxiety by asking about Gie to Ira. The new meaning constructed in this setting described Gie's life experiences in the University. Gie spent much of his time in the hall and voiced his criticism.

\section{State Financial Building}

The State Financial Building is often known as Papak Building. This building is located in Pemuda Street No.2 right next to the Barok Bridge as the main entrance for Old Town District. This building was initially known as Het Groote Huis (Big House) a square-shaped building and flat roof, built in 
1854. It later turned into a residentie kantoor or Dutch resident office in Semarang up to a century. Until finally in 1930, when Central Java Province (Provincie Midden Java) emerged, which appointed Semarang as the provincial capital, Papak Building was officially became the governor's office. Central Bank Building Jakarta

This building was burnt in 1954. Thus, they constructed a new building which is currently used as the State Financial Building. It has a Tropical Modern Architecture element and as one of the cultural heritage building which actively used by the local government, especially related to the financial activities, and one of them is the Regional Office of the Directorate of Treasury of Central Java Province (http://semarangkota.com/01/gedung-keuangan-negara/).

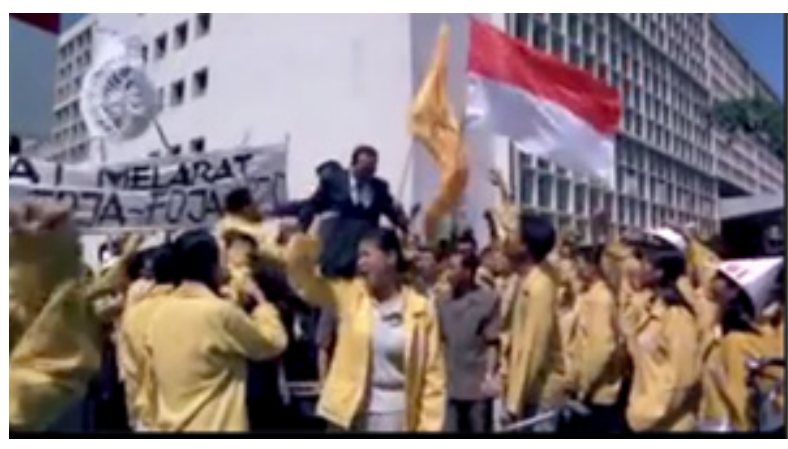

Figure 4.

The construction of State Financial Building

This building is the setting of the climax sequence of the Gie the movie. In this film, the site transformed into Central Bank Building Jakarta. The climax of this movie occurred when the student of University of Indonesia together with Gie and his friends conducted an enormous strikes to protest the current Soeharto policy and his minister at that time who were corrupt. The scene only focus on the demonstration activities. The new definition that can be taken in this place is that this place as climax scene of the movie.

\section{Ayat-Ayat Cinta the movie}

According to the movie, the named Fahri bin Abdillah is an Indonesian scholar studying for his postgraduate degree in Al Azhar University, Cairo. Maria Girgis is one of the female friends among not so many women close to him. She is a Quran admirer Coptic Christian who lives in the same flat building with Fahri and feeling to love him as well. Moreover, there is Nurul, a daughter of a famous ulama' who is alsoa student in Al Azhar. In addition, there is also Noura, a girl next door who is always abused by her own father which according to the movie script, Fahri wanted to help her. The last, there is Aisha, the girl who accidentally bumped into each other with Fahri in the public transportation and she happened to fall in love with him as well. Aisha is an typically aggressive girl who won over Fahri's heart and they got married (http://filmindonesia.or.id/movie/title/lf-a014-08997402_ayat-ayat-cinta\#.WQL8fLglHIU).

\section{Old Town (Cockfighting Site)}

This location is taken in one of the Old Town corner where is used by the Semarang inhabitants to conduct a trade transaction, chicken trade as well as cockfighting site on the daily basis.

\section{The Old Town Construction (Cockfighting site)}

In Ayat-Ayat Cinta the movie, this spot is transformed into el-ghiza market and alley separating the Fahri's and Maria's flat. This alley oftenly is shown in several scenes instead of inside of the flat. However, this is not the main focus in the movie. The scene in this spot are as followed: when showing Noura was being abbused by her father, Fahri is peeking through his flat window, when 
Aisha come as Fahri's new wife in his modest flat with her car, and when Maria is so depressed and heart broken because Fahri is married and almost get hit by a car.

\section{Lawang Sewu}

This building is a relic of the Dutch era and has stood since 1904. Previously, this building functioned as the headquarters of the Dutch railway company namely Nederlandsch Indishe Spoorweg Naatschappij (NIS). This building consists of three floors with art deco style by the famous Dutch architect, Prof Jacob F Klinkhamer and BJ Queendag. Lawang Sewu is located in the downtown of Semarang which is one of the busiest streets in the city. Literally, Lawang Sewu in Javanese term means a thousand of doors due to the many of door-like windows in that building. People simply perceive them as the building doors despite the actual doors itself do not reach a thousand pieces. Lawang Sewu was neglected for quite sometimes. Until it finally is restored and rebuilt and finished in 2011 (http://seputarsemarang.com/lawang-sewu-pemuda-1272/).

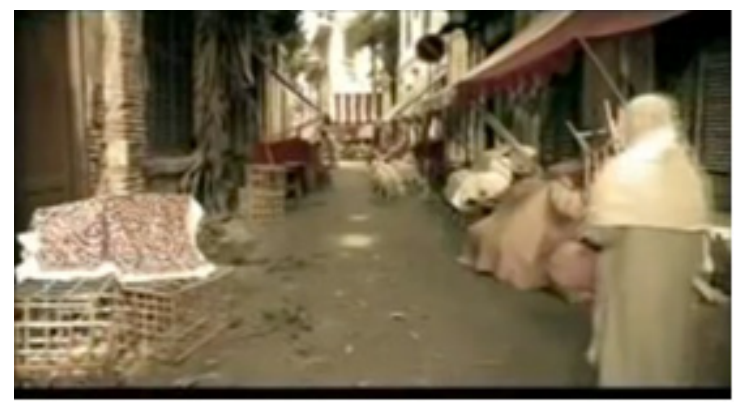

Figure 5.

Cockfighting Site

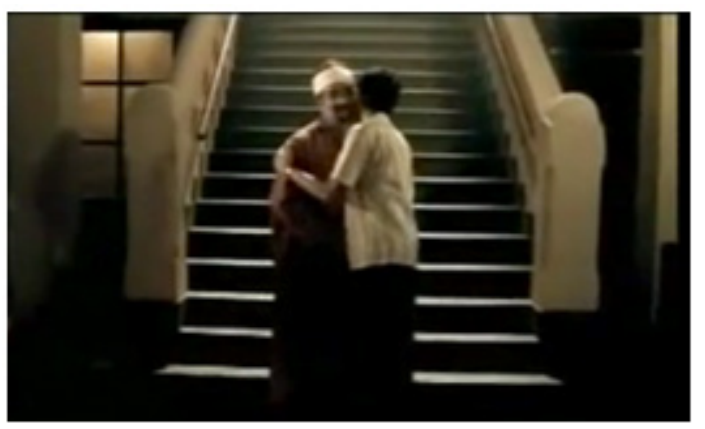

Figure 6.

Fahri boarding house

\section{The Construction of Lawang Sewu}

Lawang Sewu became the main setting-location of Ayat-Ayat Cinta the movie. This building is divided into several settings in the film such as Fahri's flat, Al Azhar University and the hospital in Egypt. The majority of the scene used Lawang Sewu building. Fahri's flat utilizes the interior of Lawang Sewu building as his residence during his stay in Egypt. Furthermore, certain areas of Lawang Sewu is transformed into a university where Fahri studies. Beside it is also used as the set of hospitals in Egypt when Maria depressed and must be hospitalized. A roomy space inside Lawang Sewu was set as the hospital in the bulkhead divider. The scene at this hospital appears at the end of the movie. These three locations can be the construction of a new meaning of Lawang Sewu

\section{Soekarno the movie}

Born by the name of Kusno, due to his frequent sickness his father replaced his name by the name of Sukarno. The hope of the skinny boy was transformed into a knight like a puppet character-Duke Karno. His father's wish was fulfilled, the twenty four years old Sukarno managed to shake the podium, shouting: "We Must Be Free Now!" as a result, he must be imprisoned. Accused of inciting 
and rebelling Sukarno's courage was never extinguished. His very famous pledo, Indonesia Sues, drove him to exile in Ende, then to Bengkulu.

In Bengkulu, Sukarno took a break from politics. His heart was tethered to a young girl named Fatmawati. Though Sukarno still as Inggit Garnasih husband, a woman twelve years older than him and always a shield for him when he was in prison and in exile. Now, Inggit must be willing to see her husband fall in love. In the midst of his domestic turmoil, Japan came waging a Great East Asia war. Soekarno's political interest returned. Despite Hatta and Sjahrir which are his political rivals, reminded that Japan was no less cruel than the Dutch, yet Sukarno had confidence. He thought that if we (Indonesian) were clever enough, we could use Japan to achieve independence. Hatta was affected, but Sjahrir did not. The progressive youth group of Sjahrir's followers even booed Sukarno-Hatta as a collaborator. Sukarno's conviction did not waver. Now, the independence of Indonesia came into being on August 17, 1945. On horse-drawn carriages, Haji Oemar Said (HOS) Cokroaminoto joins young Soekarno saying "Humans are as mysterious as nature, but if you can grasp their hearts they will follow you". This sentence always held Soekarno until he realized his dream: Indonesia Merdeka! (21 cineplex.com 2013).

\section{Berok Bridge}

Berok Bridge Semarang is a bridge built over Semarang River to connect the Old Town and Pemuda Street Semarang. This bridge is made up with four monument with one on top of it in an old-fashioned lamp. The shape of the monument is the same as the monument in front of Tawang Station. The bridge is close to several important buildings, such as the State Treasury Building, and the East side, there are Mandiri Bank, PELNI, and PTP XV.

The original function of this bridge is to connect the Old Town (Oude Stad) which covered with rectangular fortification (Fort Vijfhoek) and another town. However, after being dismantled on 1842, this bridge were neglected. This bridge is located on the West Gate or Gouvernementsport. There are several other gates such as south gate or de Zuider Port (on the front of Suari street) and east gate or Oost Port (Raden Patah street). Berok bridge was called Gouvernementsbrug but then changed into Sociteisbrug. However, this bridge is famous as Berok Bridge. Berok is actually coming from a Brug which means bridge (Seputarsemarang.com 2013).

\section{The Construction of Berok Bridge}

This location is set to illustrate of the Tunjungan Street Surabaya in the 1940s and became the opening scene after the title of the movie "Soekarno" appeared. As the opening scene of a movie, it will usually give an iconic message of a movie. In this scene the character first introduced his figure to the audience. The meaning of construction that can be built is as the opening scene Soekarno.

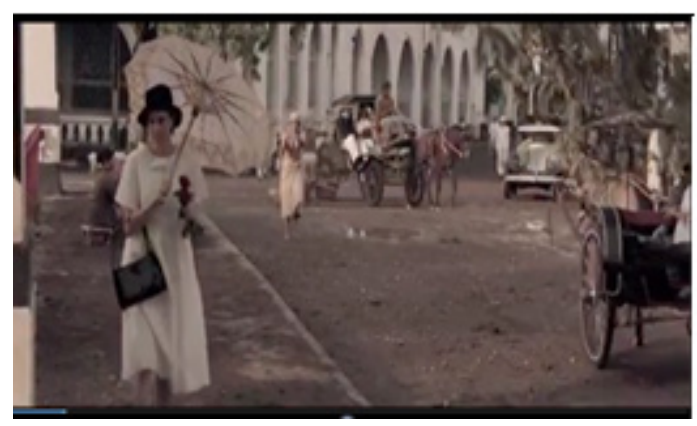

Figure 7.

Tunjungan street

\section{Blenduk Church}

Sukarno the movie use Blenduk Church as its several movie scenes. This church located in the old town district area in 1753 and it is one of the landmark in the Old Town. This building featured a neo-classical shape and was quite different compared to surrounding area and it manages to show 
contrast. It has a stunning shape. This building located in Letjend Suprapto Street No. 32 Old Town District Area Semarang and called Immanuel Church. This building has two floors and divided into three parts. This church is still used for worship every Sunday (http://seputarsemarang.com/gerejablenduk-kota-lama-1265/).

\section{The Construction of Blenduk Church}

In this film, this church is not functioned as its origins, instead it turned out into a Volksraad Building or also known as The Pancasila Building which is located in Central Jakarta, where the trial of BPUPKI was held. The flashback scene about how Indonesia's Independence finally obtained was shown in the minute $02: 16: 37$. This area become an iconic because it is consist of sequence of the history of Indonesian independence. The meaning that can be constructed in this movie is that as a place for the formulation Indonesian independence in the Soekarno the movie.

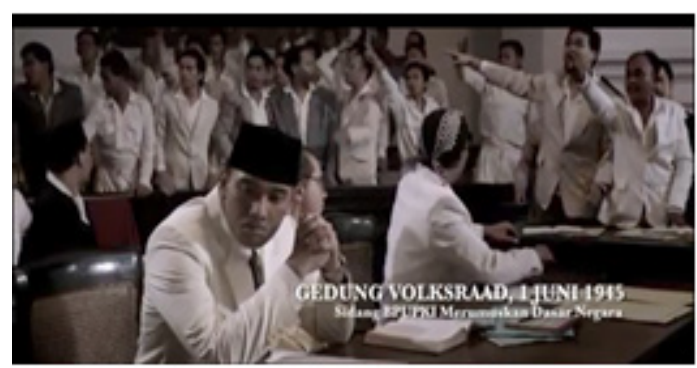

Figure 8.

\section{PT. Djakarta Lloyd Building}

Volksraad Building

Former building area of Djakarta Lloyd (XVIII century) which was located at the end of Mpu Tantular Street (d/h Wester-wal straat) and Kutilang Street (Hoofdwacht straat) is part of the Gouvernement or Dutch government office. However, this office is moved to the Papak Building afterwards.

In the early stage of building construction, the government conducted re-arrangement of area boundaries. The decision was that the Western part of the tread was cut into the same line with the other building in the south of Nederlandsche Handel Maatschappij (known as Exim Bank now), and as the compensation the northern boundary will be moved closer to the street. The architect of this building is Thomas Karsten who was assigned by the Stoomvaart Maatschappij Nederland (SMN) company, which was a shipping company designing building company with branch office in Java in 1930. This company has been built in the Netherlands before.

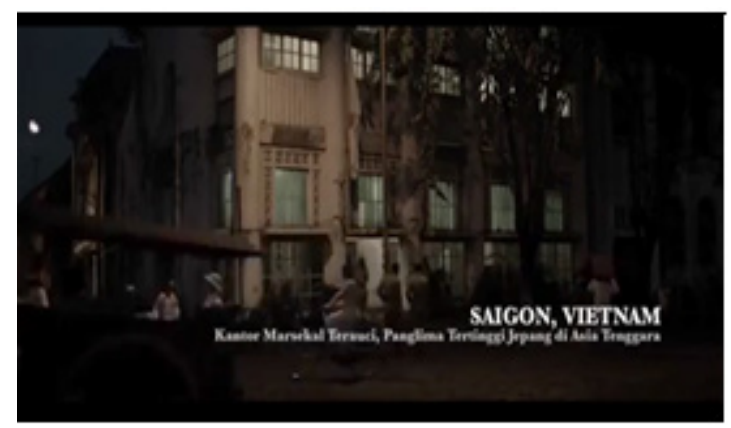

Figure 9.

The Office of Marshal Karauci Saigon Vietnam

\section{The Construction of PT. Djakarta Lloyd Building}

This building was used as the depiction of Marshal Karauci's office (Japanese Supreme Commander in Southeast Asia) which is originally located in Saigon. The scene in this building is that the Japanese 
representative met Indonesian representative, such as: Soekarno and Hatta to appoint Indonesian independence on August $12^{\text {th }}$ 1945. Then it reappeared picturing the proclamation text writing process conducted by Soekarno and Hatta. The meaning that can be constructed in this building is that this building as proclamation manuscript making office in the Soekarno the movie.

\section{Berok River}

Berok River or oftenly called as Mberok River is a river near the largest traditional marketplace in Semarang called Johar Market. The river name originally derived from Burg which in the Dutch meant 'a Brigde'. However, the Javanese people had simply called it mberok. It is the famous denomination which is used up until recent time. This river has long history since it was the main route to touch down in Semarang by the Dutch route to get to the Semarang and even by Laksamana Cheng Ho, a Chinese Moslem voyager who spread Islam in that Area. Nevertheless, this river is no longer as wide as it used to be in the past and has experienced the dysfunctioning for transportation. Recently, there are so many waste on the river causing the floods and water pollutions.

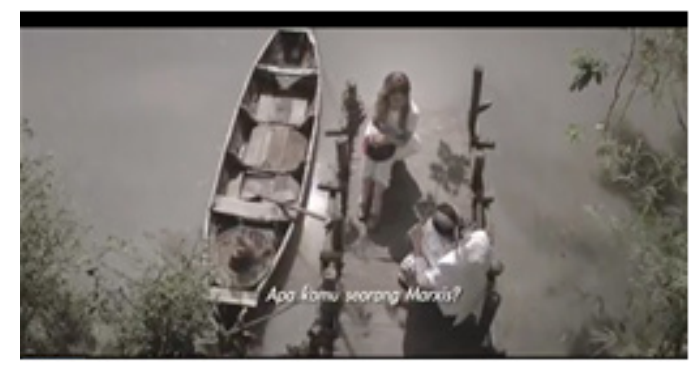

Figure 10.

Memory of Young Soekarno and Mien Hessel

\section{The Construction of Berok River}

This Chinatown district is set to describe the romantic scene between Soekarno and a Dutch Maiden called Mien Hessel. Mien is Soekarno's friends at the school who admire his work. Soekarno was about to kiss her when suddenly his father (Mr. Seokami) came and scolded him because instead of study Soekarno was dating and even worse he used his father bike, then his father asked him to go home. This scene is one of the iconic ones because it creates Soekarno romanticism since he is described to have many lovers. The meaning that can be constructed here is as a romantic scene site in the movie.

Based on the previous discussion, by using Derrida deconstruction method, in finding and building a new meaning of a location in the movie, this article found there are three separated areas in Semarang which can be built as the main points of the city branding such as the Lawang sewu Building, Imam Barjo Auditorium Diponegoro University, and the Old Town District.

Specifically located in the Old Town District there are Srigunting Park, State Financial Building, Cockfighting site, Berok Bridge, Blenduk Church, Jalarta Lloyd Building, and Berok River. In total, there are nine locations that can be developed as a tourism hub. Those locations are a brand attributes of the effort to construct a city branding Semarang City as a Cinematic City.

Figure 11 is an operationalization of the concept of the results of this study. The charts are structured based on branding theories that have been described previously. Gie movie, Ayat-Ayat Cinta and Soekarno were chosen for having a good brand image that will affect the target audience or the public. A good image will further improve the public perception of a city branding. The three selected films are then analyzed and produce brand attributes that are needed as a forming element of city branding. Brand attributes refers to areas that have the potential to become tourist attractions by 
relying on the concept of Semarang movie city. This area can later be developed into a sights based on the scenes in the film, so hopefully visitors can feel the value of satisfaction and direct experience of the atmosphere in the film. Brand attributes are, among others, the Old City Region, Imam Bardjo University of Diponegoro and Lawang Sewu Building. Of the three will be the capital forming city branding Semarang movie city.

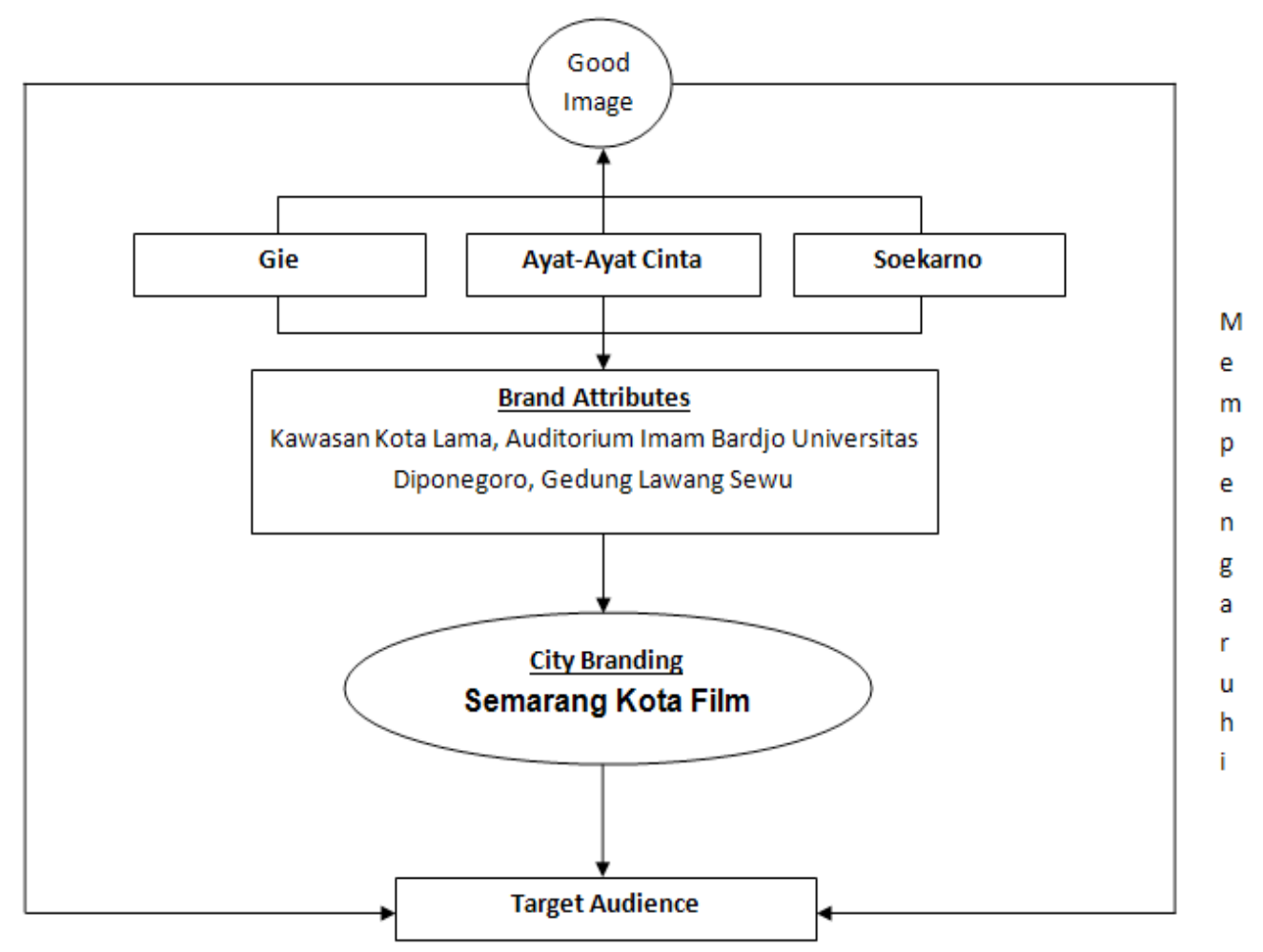

Figure 11.

Operational concept

\section{Conclusion}

This research is still aimed at finding potential locations to become the brand attributes. It suggest for further research to explore more brand attributes taking from domestic films produced in Semarang that might have big impacts among Indonesian movie lovers. Based on this research, the conclusion of some areas that have the potential to be developed into the object of city branding Semarang are Kota Lama District, Imam Bardjo Auditorium University of Diponegoro and Lawang Sewu Building. Nonetheless, this research is an only preliminary study to build the city branding which requires further investigation. Furthermore, the researcher will conduct a second stage research which is more comparative among countries that have adopted the tourism with the same concept for later on third stage research will be planned branding strategy Semarang City Film. The main benefit in this research is that it can be an alternative for Semarang government to build stronger and unique city branding, so that it can meet the target of tourists who visit Semarang.

\section{References}

Ah-young C (2016) “Descendants of The Sun' Makes Taebaek a Tourism Magnet. [Accessed 11 July 2016]. http://www.koreatimes.co.kr/www/news/nation/2016/03/116_201065.html.

Antara (2015) Genjot Pariwisata, Indonesia Terapkan City Branding. [Accessed 11 July 2016]. http:// www.beritasatu.com/ekonomi/273198-genjot-pariwisata-indonesia-terapkan-city-branding. html. 
Ayat-ayat Cinta (2008) [Accessed 28 April 2017]. http://filmindonesia.or.id/movie/title/lf-a014-08997402_ayat-ayat-cinta\#.WQL8fLglHIU.

Dinnie K (2011) City Branding: Theory and Cases. New York: Palgrave Macmillan.

Februandari A(2012) Persepsi pelaku pasar pariwisata terhadap unsur-unsur pembentuk citra destinasi (City branding Kota Semarang). Thesis, Universitas Gadjah Mada, Yogyakarta. [Accessed 15 July 2016]. http://etd.repository.ugm.ac.id/index.php?mod=penelitian_detail\&sub=PenelitianD etail\&act=view\&typ=html\&buku_id=56335.

Gedung Keuangan Negara (2014) [Accessed 1 May 2017]. http://semarangkota.com/01/gedungkeuangan-negara/.

Gereja Blenduk (2011) [Accessed 1 May 2017]. http://seputarsemarang.com/gereja-blenduk-kotalama-1265/.

Gie (2010) [Accessed 28 April 2017]. http://milesfilms.net/gie/.

Huda MN (2016) Sepanjang 2015 Jumlah Wisatawan ke Jateng Capai 33 Juta Orang. [Accessed 11 July 2016]. http://jateng.tribunnews.com/2016/02/03/sepanjang-2015-jumlah-wisatawan-kejateng-capai-33-juta-orang.

Jembatan Berok (2013) [Accessed 1 May 2017]. http://seputarsemarang.com/jembatan-berok-7599/.

Kavaratzis (2008) From City Marketing to City Branding, An Interdisciplinary Analysis with Reference to Amsterdam, Budapest and Athens. Dissertations: University of Groningen.

Kriyantono R (2009) Teknik Praktis Riset Komunikasi. Jakarta: Penerbit Kencana Prenada.

Lawang Sewu Semarang (2011) [Accessed 2 May 2017]. http://seputarsemarang.com/lawang-sewupemuda-1272/.

Lestari AW \& Firdausi F (2017) Peran pemerintah Kota Batu dalam implementasi kebijakan pembangunan pariwisata berdasarkan paradigma pembangunan berkelanjutan (Sustainable Development). Masyarakat, Kebudayaan dan Politik, 30 (3) 2017. http://e-journal.unair.ac.id/ index.php/MKP/article/view/4132/3806.

Munif A (2014) Mengenal City Branding Kota Semarang. [Accessed 11 July 2016]. http:// tabloidsimpang5.com/mengenal-city-branding-kota-semarang/.

N.N. (2014) Logo City Branding Semarang Dikecam di Media Sosial. [Accessed 14 July 2016]. http://metrosemarang.com/logo-city-branding-semarang-dikecam-di-media-sosial.

N.N. (2017) Taman Srigunting Kota Lama Semarang: Parade Plein. [Accessed 01 May 2017]. https:// seputarsemarang.com/taman-srigunting-kota-lama-semarang-parade-plein/.

Pemerintah Kota Semarang (2015) [Accessed 14 Juli 2016]. http://semarangkota.go.id/berita.

Penerimaan Peserta Didik Kota Semarang Tahun Pelajaran 2017/2018 (2017) [Accessed 14 July 2016]. http://ppd.semarangkota.go.id/portal/veriety.html.

Petrauskaite E (2014) Effect of brand image on consumer purchase behaviour: International Footwear market comparison. Thesis, Aalborg University. [Accessed 16 July 2016]. http://projekter.aau. dk/projekter/files/198320070/Master_Thesis_Egle_Petrauskaite.pdf.

Soekarno (2013) [Accessed 28 April 2017]. http://www.21cineplex.com/soekarno-movie,3322, 03SOEO.htm.

Soliha E, Rozak HHA, Basiyo R, \& Purwanto U (2014) Pengaruh city branding terhadap keputusan berkunjung ke Kota Semarang. Thesis, Program Pascasarjana Universitas Stikubank. [Accessed 15 Juli 2016]. http://www.unisbank.ac.id/ojs/index.php/fe10/article/download/3850/1113.

Sutopo (2002) Metode Penelitian Kualitatif. Surakarta: UNS Press. 
Turiman (2015) Metode semiotika hukum Jacques Derrida membongkar gambar lambang negara Indonesia. Jurnal Hukum dan Pembangunan, 44 (2) April-June 2015. jhp.ui.ac.id/index.php/ home/article/download/6/5.

Turner C(2016) Jacques Derrida:Deconstruction.[Accessed21 April2017].http://criticallegalthinking .com/2016/05/27/jacques-derrida-deconstruction/.

Moilanen T \& Rainisto S (2009) How To Brand Nations, Cities And Destinations. A Planning Book for Place Branding. New York: Palgrave Mamillan.

Moleong LJ (2010) Metode Penelitian Kualitatif. Jakarta: Rosda Karya.

Mowen JC \& Michael M (2002) Perilaku Konsumen Jilid 1 Edisi Kelima. Jakarta: Penerbit Erlangga. [Accessed 16 July 2016]. http://www.managementstudyguide.com/brand-attributes.html. 